\title{
Reaction of inducible hsp70 form on different environmental conditions in Ommatogammarus flavus
}

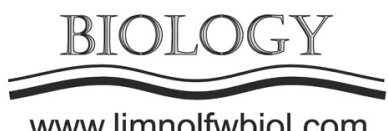

www.limnolfwbiol.com

\author{
Shirokova Yu.A. ${ }^{1 *}$, Madyarova E.V. ${ }^{1,2}$, Shatilina Zh.M. ${ }^{1,2}$, Shmatov F.M. ${ }^{1}$, \\ Timofeyev M.A. ${ }^{1,2}$
}

${ }^{1}$ Irkutsk State University, Lenin Str., 3, Irkutsk, 664025, Russia

${ }^{2}$ Baikal Research Centre, Lenin Str., 21, Irkutsk, 664003, Russia

\begin{abstract}
The aim of the research was to estimate heat shock protein expression under the change in ambient temperature and hydrostatic pressure in Baikal deep-water amphipods Ommatogammarus flavus. The expression of the constitutive hsp70 transcript did not change in response to the influence of both environmental factors. The inducible $h s p 70$ form did not differ after the change in hydrostatic pressure in amphipods captured from the depth of 50 and $750 \mathrm{~m}$. High expression of inducible $h s p 70$ transcript was shown during gradual increase in ambient temperature when it reached $22^{\circ} \mathrm{C}$. The detected increase in $h s p 70$ expression is associated with the cells reaction to protein damage at the high temperature. Thus, the studied hsp70 inducible form is involved in the adaptation to change in ambient temperature in $O$. flavus despite the fact that this species inhabits the deep-water zone with stable temperature conditions. It is necessary to analyze other isoforms of $h s p$ in the further studies to find those that participate in the adaptation to high hydrostatic pressure.
\end{abstract}

Keywords: Baikal, amphipods, adaptations, heat shock proteins, hydrostatic pressure, temperature

Only in Lake Baikal, there is a freshwater fauna of amphipods that inhabit the deep-water zone. Among Baikal deep-water amphipods, the eurybathic species Ommatogammarus flavus is of great interest. This species inhabits a narrow range of temperatures $\left(4 \pm 0.5^{\circ} \mathrm{C}\right)$ but a wide range of hydrostatic pressures (1.3-130 atm) (Bazikalova, 1945; Kozhova and Izmest'eva, 1998). Brown and Thanje (2014) report that adaptations to temperature and high hydrostatic pressure are interconnected. Several isoforms of heat shock proteins, which are known to protect the cells from the damage caused by different types of stressors, may be involved in the adaptation to high hydrostatic pressure (Ritchie et al., 2018). The purpose of the study was to assess the expression of heat shock protein transcripts (hsp70) under the change of ambient temperature and hydrostatic pressure in Baikal deep water amphipods O. flavus.

The amphipods were collected at Lake Baikal (Bolshie Koty bay) from the depths of 50, 100 and $750 \mathrm{~m}$. Animals from the depths of 50 and $750 \mathrm{~m}$ were fixed in liquid nitrogen right after sampling. The amphipods from $100 \mathrm{~m}$ depth were acclimated in the laboratory conditions during 7 days at $4^{\circ} \mathrm{C}$. After that, the acclimated animals were exposed to the gradual increase $\left(1^{\circ} \mathrm{C}\right.$ per hour) of the ambient temperature from $4^{\circ} \mathrm{C}$ (control group) to $22^{\circ} \mathrm{C}$ and fixed in liquid nitrogen. The expression of constitutive and inducible forms of $h s p 70$ genes was determined with quantitative reverse transcription polymerase chain reaction. Two pairs of primes (Protopopova et al., 2014; Drozdova et al., 2019) were used for these genes. Gpdh was used as a reference gene for the calculation of $\Delta \mathrm{C}_{\mathrm{T}}$.

It was shown that the expression of both constitutive and inducible $h s p 70$ was at the low level and did not differ in the individuals of $O$. flavus captured from the depths of 50 and $750 \mathrm{~m}$ (Fig.). The level of expression in constitutive $h s p 70$ was 6-fold higher in the amphipods from $50 \mathrm{~m}$ and 9-fold higher in the individuals from $750 \mathrm{~m}$ then in inducible form. The expression of the studied $h s p 70$ isoforms was at the low level in the control group of the amphipods (after 7 days of laboratory acclimation). In this group, the expression of constitutive $h s p 70$ was up to 40 -fold higher in comparison to the inducible transcript. Inducible $h s p 70$ expression enhanced during experimental exposition under gradual increase of temperature. In this case, the expression increased 124-fold in comparison to the control value when the temperature reached $22^{\circ} \mathrm{C}$. At this temperature, the level of expression was 3 times lower in constitutive $h s p 70$ then in inducible.

The fact that the expression of constitutive and inducible $h s p 70$ did not differ in $O$. flavus from different depths indicates that the studied HSP70 proteins are 
A

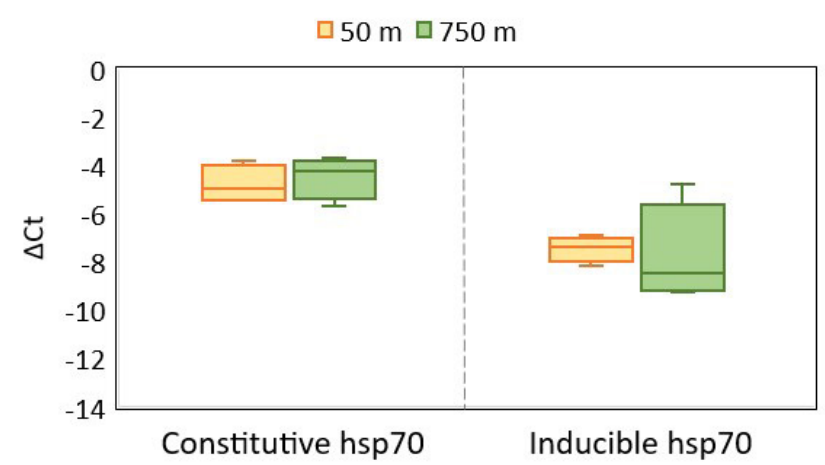

B

Temperature

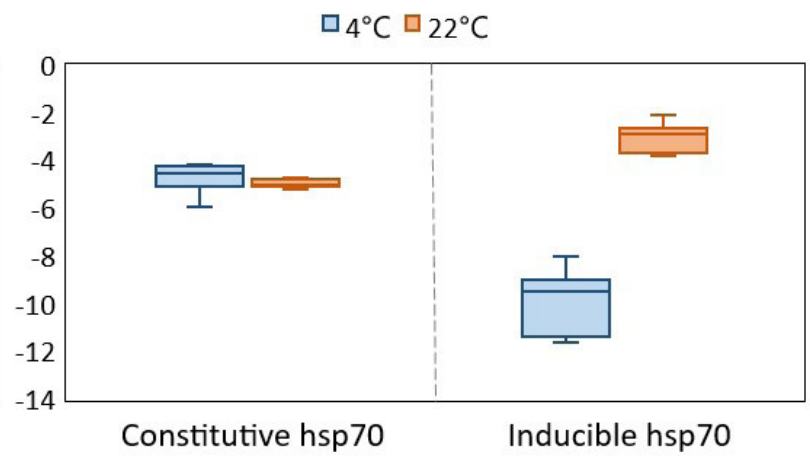

Fig. Reaction of constitutive and inducible $h s p 70$ on the change of hydrostatic pressure $(A, n=4)$ and temperature $(B, n=8)$.

probably not involved in the adaptation to change of hydrostatic pressure. The detected elevation of inducible $h s p 70$ expression during the increase of the ambient temperature in studied species is connected with the reaction of cells to the proteins damage.

In spite of our knowledge that $O$. flavus mostly inhabits the deep-water zone in the conditions of stable low temperature, the expression of $h s p 70$ in this species increases in the response of increase of temperature. Thus, increase of $h s p 70$ expression, conservative mechanism of heat shock response common for the majority of the species, participates in the adaptation of $O$. flavus to change of temperature. Further investigations should be focused on the search of heat shock protein isoforms that protect the proteins from changes in hydrostatic pressure.

\section{Acknowledgments}

This study was supported by the Russian Science Foundation / Helmholtz Association of German Research Centres (RSF grant number 18-44-06201).

\section{References}

Bazikalova A.Ya. 1945. Amphipods of Lake Baikal. Trudy Baykal'skoy Limnologicheskoy Stantsii [Proceedings of the Baikal Limnological Station] 11: 1-440. (in Russian)

Brown A., Thanje S. 2014. Explaining bathymetric diversity patterns in marine benthic invertebrates and demersal fishes: physiological contributions to adaptation of life at depth. Biological Reviews 89: 406-426. DOI: 10.1111/ brv.12061

Drozdova P.B., Bedulina D.S., Madyarova E.V. et al. 2019. Description of strongly heat-inducible heat shock protein 70 transcripts from Baikal endemic amphipods. Scientific Reports 9. DOI: 10.1038/s41598-019-45193-0

Kozhova O.M., Izmest'eva L.R. 1998. Ozero Baykal. Evolyutsiya i bioraznoobraziye [Lake Baikal. Evolution and biodiversity]. Leiden: Backhuys Publishers.

Protopopova M.V., Pavlichenko V.V., Menzel R. et al. 2014. Contrasting cellular stress responses of Baikalian and Palearctic amphipods upon exposure to humic substances: environmental implications. Environmental Science and Pollution Research 21: 14124-14137. DOI: 10.1007/ s11356-014-3323-8

Ritchie H., Jamieson A.J., Piertney S.B. 2018. Heat-shock protein adaptation in abyssal and hadal amphipods. Deep-sea Research Part II 155: 61-69. DOI: 10.1016/j.dsr2.2018.05.003 